\title{
Yeni Fizikten Kaynaklı Dilde Meydana Gelen Dönüşümler
}

\section{The Transformations in Language Due to New Physics}

\author{
Ayhan Aksakall1 a,* \\ ${ }^{\text {a }}$ Dr, Fen Bilimleri Öğretmeni, Milli Eğitim Bakanlığı, Erzurum/Türkiye. \\ ORCID: 0000-0001-6281-5828
}

\section{MAKALE BİLGİSI}

\section{Makale Geçmişi:}

Başvuru tarihi: 19 Eylül 2019

Düzeltme tarihi: 25 Kasım 2019

Kabul tarihi: 04 Aralık 2019

\section{Anahtar Kelimeler:}

Klasik Fizik

Modern Fizik

Bilim Dili

\section{A R T I CLE INFO}

\section{Article history:}

Received 19 September 2019

Received in revised form 25 November 2019

Accepted 04 December 2019

\section{Keywords:}

Classic Physics

Modern Physics

Language of Science
ÖZ

Bu makalenin amacı bilimdeki gelişmeler ile beraber dilin de genişlediğini göstermektir. Fiziğe katılan yeni teoriler beraberinde çok ciddi sorunları gündeme getirmiştir. Özellikle görelilik ve kuantum teorileri olarak da bilinen "yeni fizik", önümüze açılan bilimsel gerçekliğe ayak uydurabilme adına bizleri uygun bir bilim dili arayışına mecbur bırakmıştır.

Determinist-mekanist şemayı zedeleyen yeni fizik, bilimsel camianın kullandığı dilin algılayış biçimini de değiştirmiştir. Bu durum sadece bilim insanlarının değil bu dili kullanan birçok kesimin de bilimsel gerçekliği tanımlamak için kullandıkları gündelik dili değiştirme ihtiyacını hissettirmiştir. Diğer bir ifadeyle bu durum yeni fizikle beraber fizikte kullanılan kavramların türlerini ve alanlarını da değiştirmiştir.

\section{A B S T R A C T}

The aim of this article is to show that language has expanded along with the progress of scientific knowledge. The new theories involved in physics brought along serious problems. New physics, also known as relativity and quantum theories, forced scientists to seek a proper scientific language to keep up with the scientific reality brought before them.

The new physics, which damaged the determinist-mechanist schema, also changed the perception of the language used by the scientific community. This was true not only for scientists, but also for many people who had to change their everyday language to define scientific reality. In other words, it has changed the types and fields of concepts used in physics with new physics.

\section{Giriş}

"Kelimelere ancak istenilen bir șey yok olduğunda ihtiyaç duyulur; kayıp olmayan yerde dil var olamaz."

Jacques Lacan

20. yy’a kadar fiziğin daha çok kesinlik yönünden ilerlemesi fiziğin büyük bir kısmının gündelik dil ile ifade edilmesiyle öne çıkmıştır. Öyle ki kanıtlama gerektiren fiziksel olgular az sayıda mekanik kuralla yapılabiliyordu (Nagel \& Newman, 2010). 20. yy başlarına kadar egemen olan Newton fiziği, fizik tarihi içerisindeki önemli argümanlardan biridir.

* Sorumlu yazar/Corresponding author. e-posta: tolga250606@hotmail.com
Güneş, gezegenler ve yıldızlar gibi büyük kütleli cisimlerin davranışları bu fizik kullanılarak rahatlıkla öngörülebiliyordu. Bu anlamda adeta tanrısallığa bürünen Newton fiziği, hareket olgusunu yeryüzü ve gökyüzü ayrımı yapmadan günümüzde halen daha kullanılan gündelik dil ile açıklayabilen bilimsel bir çalışmanın ilk ve en olgun örneği olarak bilim tarihinde yerini almıştır (Ural, 1998, s. 271283).

20. yy'a kadar insanların Newton fiziğine bu kadar hayranlıkla bakılması belki de çiftçi bir ailenin çocuğu olması ya da din ve din tarihi ile ilgili yaklaşı üç milyon kelime kaleme almış olmasından kaynaklandığı düşünebilir. Tabiatıyla gerek bilim gerekse simya alanında yazdıklarının 
aslında dini motivasyonla yazması 20. yy'a kadar reddedilemez şekilde büyük bir hayran kitlesini de açı̆̆a çıkardığı ayrıca söylenebilir (Ural, 1998, s. 271-283).

20. yy'a kadar egemen olan dil özellikle "doğa felsefesinin matematik ilkeleri" ile birlikte yepyeni bir evren tablosu çizerek felsefede ve bilimde yeni bir yöntem olan hipotetikdedüktif evren tanımlamasının kapısını açmıştır (Ural, 1998, s. 271-283). Dolayısıyla bu yüzyılın dili sadece bilimsellik açısından değil yöntemsel açıdan da gerek bu çağı gerekse bu çağın insanlarını yakından etkilemiştir. Bu yüzyılın en büyük özelliklerinden biri determinist-mekanist dili egemen kılması olarak karşımıza çıkmaktadır. Çünkü Newtoncu paradigmaya göre bilim ve her şey sonuçtan sebebe doğru hareket ediyordu. $\mathrm{Bu}$ görüşün kullandığı dil o kadar güçlüydü ki günümüzde dahi halen birçok felsefeci ve bilim insanlarında görmek mümkündür. Özetle Newton'un Principia'sından kaynaklanan dili 20. yy'a kadar duymak bilimsel dilin evrimselleşme süreci içerisindeki adımlardan birisiydi (Ural, 1998, s. 271-283).

19. yy ile doğa bilimlerinde ileri sürülen yeni fikir ve buluşlar yeni bilimsel tartışmaları da gündeme getirerek, bir önceki dönemin bilimsel dil birikimlerinin yetersiz olduğunu ileri sürüp kuvvet, kütle, hız, enerji ve momentum gibi kavramların sadece büyük kütleler üzerinde ses getirebildiğini deklare ederek 17. yy fiziğini bilimsel dil açısından başarısızlık olarak değerlendirmiştir. (Smolin, 2018) 19. yüzyılla birlikte bilim dili, büyük bir hızla evrilip yeni fikirlerin ve yayınların doğmasına zemin hazırlayarak (Öner, 2000) bilimin varlıklı amatörlerin uğraşı olmadığını ortaya çıkarmıştır (Smolin, 2018).

19. yy’la birlikte açı̆̆a çıkan yeni bilimsel dil ne kadar evrilirse evrilsin istediği etkiye bir türlü erişememiştir (Öner, 2000). Newtoncu paradigma derinlere öylesine nüfuz etmişti ki Antoine Lavoisier'in niceliksel kimya deneyleriyle maddenin korunduğunu gösterdiği 1780 yılında Isaac Newton'un hareket ve kütle çekim yasaları neredeyse yüzüncü yılını dolduruyordu. Newton bize doğanın tümünü anlamak için gerekli bilimsel dili sunuyordu. Fakat sınırlar yine de zorlanmaya değerdi. İnsanlar madde, 1şık, 1sı elektrik ve manyetizma ile ilgili uygun bilimsel dili öğrenmeye meraklıydı (Smolin, 2018). Öyle ki bu durum, rölativite ve kuantum teorisi olarak bilinen yeni fiziğin açıklanışına kadar devam etti (Öner, 2000).

\section{Yeni Fizik}

20. yüzyılın başlarında Max Planck'ın kuantum teorisi ile temelleri atılan kuantum fiziği ve A.Einstein'ın öne sürdüğü özel ve genel rölativite teorisi, Newton fiziğinin yerini almaya başladı. Newtoncu paradigmanın yerini fizikteki iki büyük devrimin almış olmasıyla yeni fizik başlamış oldu (Davies, 1994). Özel rölativite teorisi üç boyutlu uzay dokusuna zaman boyutunu ekleyerek dört boyutlu yeni bir uzay-zaman sürekliliğinden bahsediyordu. Bu teoriye göre zamanın evrensel ve sürekli olduğu kolay bir şekilde iddia edilemezdi. Gözlemlenen herhangi bir olayı farklı hızlarda hareket eden farklı iki gözlemci farklı zamanlarda algılayacaklardı (Davies, 1994). Dolayısıyla herhangi bir gözlemci aynı anda oluyormuş gibi algılasa da başka bir gözlemci aynı olayları farklı bir zamanda ortaya çıktığını hissedecekti. Ortaya çıkan bu garip durumlar doğal olarak uzay ve zamana bakış açısını değiştirerek mutlaklığına karşı olan inancı da değiştirmiştir. Uzay-zaman kavramlarındaki bu değișiklik tabiatıyla doğayı açıklamak için kullanılan kavramların dilinde de bir değişiklik meydana getirmiştir. Yeni fiziği oluşturan kuantum ve rölativite teorisinin kullandığı dil, fizikçilerin gerçekliğe olan bakış açısını değiştirerek uzay-zaman, madde, neden- sonuç kavramlarında köklü değişimlerin meydana gelmesine neden olmuştur. Açığa çıkan bu yeni dil organik, bütüncül ve ekolojik gibi terimlerle nitelendirilerek Newton paradigmasında egemen olan bölünemez, parçalanamaz bütünlük anlayışının yerine parçalanabilir hatta dönüşebilir bir dili gündeme getirmiştir ( Davies, 1994). Bu dönüşebilirlik içerisinde özellikle maddenin ikili görünümünün (dalga/parçacık) enerjiye dönüşebilirliği, iki üç boyutlu bir uzay-zaman dokusundan 4-5 boyutlu uzayzamana olan evrimlemesi örnek olarak verilebilir. Capra'ya (1989, s. 64-75) göre dilde meydan gelen bu dönüşebilirlik insan bilinci ile atomik süreçler arasında çok yakın bir ilişki olduğunu göstererek evrenin birbirine örülü bir ilişkiler ağından meydana geldiğini ileri sürmüştür.

Yeni fizikle beraber dilde meydana gelen dönüşümler evreni ve onun denklemlerini tanımlayabilmek adına yeni kapılar açsa da günümüzde dahi istediği etkiye erişemediğini de ayrıca görmekteyiz (Öner, 2000). Öyle ki günümüz fizikçilerinin kuantum ve rölativite teorilerini halen Newtoncu dil ile açıklama gayreti içerisinde olmaları bu durumun en güzel göstergelerinden birisidir (Aksakallı, 2019).

Yeni fizik dili beraberinde bir tepki dalgası yaratmış ve bu dalga genişleyerek tüm doğa bilimlerinin kapısını çalmıştır. $\mathrm{Bu}$ durum ise yeni fiziğe kadar bilimlerin dayanak bulduğu dil, savunucularının ayaklarının altından kayıp gitmesine neden olmuştur (Öner, 2000). Özellikle bilimsel süreçleri ifade etmek için kullanılan determinist-mekanist dil tahribata uğrayarak fizikçilerin neden-sonuç ilişkisinden yola çıkıp bir sonuca bağladıkları deneysel sonuçların mutlu bir tablo yaratmadığını fark ettirmiştir. Bunun yanı sıra fizikçi olmayan kesime yeni dilden kaynaklı olguları tanımlayabilmek adına gerekli dilin sunulmamış olması da Newtoncu paradigmadan kaynaklı fizik dilinin, fiziğin başlangıcından beri bilinmeyenlerle yüzleşen nihai bir dil olmadığı gerçeğini de göstermiştir (Smolin, 2018).

Yeni fizikle birlikte dilde meydana dönüşümler deney sonuçlarını anlatmak ve tanımlamak açısından bir kriteryum doğurarak ilgili konu ya da konuların kavranış derecesi bakımından bir takım problemleri gündeme getirmiştir (Öner, 2000). Bu problemler içerisinde özellikle deneylerden elde edilen sonuçların determinist-mekanist bir dil ile ifade edilmesi durumunda sonuçların tanımlamalarının nasıl yapılacağı ve sınırlarının nereye kadar uzanacağı şeklinde sorularla bizleri baş başa bırakmıştır (Öner, 2000).

\section{Genel ve Bilimsel Açıdan Dil}

Ergin'e (2013) göre dil, insanlar arasında anlaşmayı sağlayan tabii bir vasıtadır. Wittgenstein'e göre ise dil bizim organizmamızın bir parçasıdır ve ondan daha az karmaşık değildir (akt. Soykan, 2016, s. 51-53).

Foucault (2017) da ise dil farklı bir şekilde kendini göstermektedir. Şöyle ki Foucault (2017) dilin, önce ham ve ilkel varlığ 1 içinde, bir yazının, şeyler üzerinde ki bir izin, dünyaya yazılmış olan ve onun en silinmez figürlerinden 
birini meydana getiren bir işaretin basit ve maddi biçimi olarak kendini gösterdiğini ifade eder.

Öner (2000), dilin oluşumu hakkında kesin bilgilere sahip olmadığımızı ileri sürerek günlük hayatta karşılaştığımız kavramların anlamlarına yönelik bir araç olarak dilin aynı zamanda birçok kavramı da kapsadığını ifade etmektedir. Bu kavramlar yıllardan beri insanoğlu tarafindan kullanıldığından dolayı ne anlama geldiklerini bildiğimizi sanırız. Foucault (2017) bu durumu dilin, üç dil düzeyinden birisi olduğunu söyleyerek dilin kavramsal tabakasının bir bakıma eşsiz ve mutlak olduğunu söyleyerek bu tabakanın aynı zamanda onu çevreleyen iki söylem biçimini de yarattığını belirtmektedir. Bu söylem biçimleri; üstünde yeni bir söylem halinde verilen işaretleri yeniden ele alan yorum ve altında yorumun herkes tarafından görülebilir nitelikteki işaretlerin önceliğinin varsayıldığı metinlerdir. Örneğin bir adet odun ya da teneke diyebiliriz. Fakat metinlere bir bütün olarak baktığımızda bir adet su denilemeyeceğini görürüz. Çünkü saklı kalan öncelikli metinlere göre adet sözcüğü akışkan cisimler için kullanılamaz (Öner, 2000). Sözcüklerin anlamlarında yatan bu kesinsizlik şimdiye kadar bilinmeyen yeni bir sorunun ortaya çıkmasına neden olmuştur. 17. yy kadar bir sözcüğün işaret ettiği şeyi nasıl gösterdiği sorulmaktaydı. 17. yy'dan itibaren ise bu işaretin işaret ettiği şeye nasıl bağlanabileceği sorulmaya başlanıldı (Foucault, 2017).

Klasik dönem bu tür sorulara temsil çözülmesi aracılığıyla cevap verirken modern çă̆ anlam ve anlam verme stratejisini dikkate alarak cevapliyordu. Sözcüklerin anlamlarında yatan kesinsizlik (Öner, 2000) dünya ile dilin birbirlerine karşı olan derinlemesine aidiyetlerini bozarak (Foucault, 2017) sözcüklere farklı anlamlar yüklenen bir durum olarak kendini göstermiştir. Heisenberg (1964:155163) bu durumu "yaptığımız tanımlamaları başka tanımlar yardımıyla yerine getirebilmemiz bizi sadece varlığına sığındığımız birkaç temel kavrama güvenmek zorunda bırakmıştır" şeklinde ifade etmektedir. Dilde ki kavram problemi antik yunan felsefesinde de karşımıza çıkmaktadır (Öner, 2000). Bu duruma varlık ile düşünce, sözcük ile anlam bağlantısı dikkate alınarak felsefi bir göz ile bakılmaya çalıșılmıştır ( Yüksel, 2009). Sözcük, varlığın bir simgesi, adlandırılması, göstergesi değil, onun gerçek bir parçası; dışsal bir örtüsü, dil ise bilginin temeli olarak görülmüştür. Platon sözcükler içerisinde nesnel hakikate ulaşılamayacağı kanısındaydı. "Düşünme" yalnızca kendisine dayandırılması ve kendisini hakiki nesnelerine, yani idelerine açmalıydı" (akt. Altuğ, 2000: 15-16). Platon Kratylos diyalogunda nesnelere verilen adların doğruluğundan bahsederken şöyle der: " Hem de konuşurken düşündüğüm şeye benzemeyen bir şey vasitasıyla bildiriyorum. Zira Sklêrotês dediğin şeyle l (lenta) arasında bir benzerlik yok" (Yüksel, 2009, s.153-154). Platon felsefesinde sözcük ve nesne öyle bağlıdır ki sözcük şeyi (nesneyi) düşüncede temsil eder. Ancak düşünme sadece kendisine dayanmalı ve kendisini hakiki nesnelerine açmalı kanısında olan Platon'a göre sözcükler düşünce için zorunlu öğeler değillerdir (Akarsu, 1998).

Aristoteles, bilimsel bilginin elde edilmesinde kural ve aşamaları ele alıp bilimsel bilginin olanaklı olup olmadığını açığa çıkarmıştır. Başka bir deyişle apodeiktik bilginin hangi disiplin içerisinde nasıl gerçekleştiğini anlamaya çalışmıştır. Bunun yanı sıra dilde uygulanan biçimleri çözerek yaptığımız çıkarımlar ve bunların sonuçlarına özgü bilimsel bir yapıyı ortaya koymuştur (Heisenberg, 1964). Aristoteles'in dildeki çözümlemeleri Aristo mantığı olarak bilinen ilk mantık bilimini ortaya çıkararak düşünme yöntemimizde belirli bir anlatım düzeninin kurulmasına ve dilin bir açıklık kazanmasına da öncülük yapmıştır (Öner, 2000).

\section{Tartışma}

\subsection{Doğa Bilimleri ve Dil}

Wittgenstein "olgular hepsi birden dünyadır" (akt. Soykan, 2016, s. 51-53) diyerek dünyanın yapısını çözümlemek adına cümlelerin hepsinin bir dil olduğunun düşünülmesi gerektiğini ileri sürmüştür. Doğa bilimlerinde anlaşma aracı olarak dilin kullanması bir bakıma Wittgenstein'in sözlerini destekler mahiyettedir. Özellikle sözcükler ve onların değişik anlamlara gelmesi (Öner, 2000) olguların yarattığı farklı dil süreçlerini açığa çıkarmaktadır. Farklı dil süreçleri özellikle bilimsel konularda mantıksal çıkarımları daha önemli kılmaktadır. Bu anlamda mantığın taraf olduğu tek anlamlı ifadeler sağlıklı olmayacağı gibi birçok problemi de beraberinde getirecektir. Özellikle tikel ve tümeller arasında hissedilebilir zorluklar doğuracaktır (Öner, 2000). Bilindiği gibi doğa bilimlerinde tikel olandan tümel olanı elde etme çabası alışılagelmiş bir reflekstir. Başka bir deyişle tikel olayları basit ve genel yasaların bir nedeni olarak değerlendirmektedir (Öner, 2000). Bu tikel olaylar dil nosyonu ile ifade edilmek istenirse bu durumda ancak sayılı birkaç kavrama indirgenmiş oldukları görülür (Heisenberg, 1964).

Cassirer'e (2005) göre tek olan yani kendine özgü ve sınırlanmış bir var olan, kendisinden varoluşla ilgili bütün diğer şeyleri çıkarıp açıklamak için kavranır. Bu anlamda kökende olup fakat sınırları çizilmiş tikel olaylar ve bunlara ait olan birçok kavramın yeniden aydınlatılması gerekmektedir. Öyle ki bu tikel olayları sadece nitel açıdan ve hiçbir kesinlik taşımadan türetmek yerine teker teker ve en ince ayrıntılarına kadar büyük bir kesinlikle tanımlamak gerekmektedir (Öner, 2000).

Kullandığımız gündelik dil ile tikel olayları ve ona özgü kavramları tanımlamaya çalışmak şu an içerisinde bulunduğumuz bir yanılg1 gibi durmaktadır. Özellikle gündelik dil ile tikel olay ve kavramların genel yasalardan mantıksal çıkarımlar yoluyla elde edilemeyeceğini söyleyebiliriz (Heisenberg, 1964).

Yukarıda tikel olaylar ve kavramlarla ilgili bahse konu olan söylemler doğa bilimleri içinde geçerlidir. Örneğin fizikçiler, fizikteki olayları ve bunların neden olduğu olay gruplarını matematiksel semboller kullanmak suretiyle anlamaya çalıșırlar. Sembollerin her birini isimlendirerek bu sembollerin yardımı ile olgular ve sonuçları arasında bağlantı kurup gündelik dil ile olan ilişkisini anlama gayretine girişirler. $\mathrm{Bu}$ gayret sonucunda semboller ve sonuçları ile ilişkili kesin kurallı bir sistem inşa etmiş olurlar (Heisenberg, 1964). Böyle bir sistemi tanımlayabilmek adına ise fizikçiler kendi tanım ve aksiyomlarını geliştirerek sisteme uygun sembol ve ilişkili denklemsel dili ilan ederler (Öner, 2000). Bu ilanla birlikte ortaya çıartılan matematiksel şema dikkate alınan olayları açıklayarak, onlara ithaf edilen sembollerle arasındaki bağı daha güçlü kılma imkanına kavuşur. Bu bağ, sembol ve ölçü arasındaki 
ilişkinin gündelik ile ifade edilebilecek anlamını doğurarak sembol, ölçü ve matematiksel şemanın gündelik dil ile ifade edilebilmesine yönelik yapılan mantıksal çıkarımların da haklı olduğu anlamını doğuracaktır. (Öner, 2000).

\subsection{Yeni Fiziğe Ait Örnek Doğa Olayları ve Dil}

Geçen yüzyılın en büyük sarsıcı devrimlerinden olan özel ve genel rölativite teorileri ile kuantum teorisi doğa bilimlerinde ciddi çatlaklar meydana getirmiştir (Arı, 2015). Bu çatlaklardan ilki rölativite teorileri ile kendini gösterip özellikle özel rölativite teorisi olaylar arasındaki bağıntıları konumsal bağımlı yapma hususunda spekülatif fikirlerin ortaya çıkmasına neden olmuştur. Bertrand Russel'ın (2013) ifadesiyle klasik tanımlamalara kadar mutlak fakat konumlardan bağımsız olan rölativite teorisi fizik çalışmalarındaki klasik bakış açısının, 20. yy' daki kavranışını, Newton'un belirlediğinden daha güçlü bir hale getirmiştir. Bu anlamda Kant'ın mutlak uzay ve mutlak zaman gibi birbirinden bağımsız ontolojik yapıları, dış algiların temelinde olan zorunlu a priori olmaktan çıkarıyordu (Russell, 2013). Rölativite teorileri Kant'ın doğa yasalarının tümevarımsal bilgisine ulaşabileceğimiz düşüncesini sekteye uğratarak Humen'un kuşkucu itirazını daha çok ön plana çıkarmıştır (Russell, 2013). Bu kuşkucu itiraz özellikle uzay ve zaman kavramlarına bakış açısını değiştirerek bu kavramları yeniden tanımlamak adına nasıl bir dil kullanılması gerekliliğini çözülmesi gereken bir sorun olarak ortaya koymuştur (Öner, 2000).

\subsection{Rölativite Teorileri ve Dil}

Bilim tarihindeki mucize yıllar içerisinde 1905 yılının özel bir yeri vardır. 1905 yılında Einstein beş olağanüstü çalışma yayınlamıştır. Bunların hepsi de kendi içerisinde önemli bir yere sahiptir. Ancak bu çalışmalardan iki tanesi gerçekten fiziğin çehresini değiştirmiştir (Hoffman, 1992). Özellikle özel rölativite teorisi hızların 1şık hızına kıyasla çok küçük olmaları durumunda açığa çıkan epistemolojik değerlendirmelerde eski fizikle yakın temasa geçerek hem geçmişte hem de çağımızda önde gelen fizikçilerin yazılarını, sürdürmekte olan araştırmaların düşünsel yönelimini birlikte ele almalarına neden olmuştur (Cassirer, 2008).

Rölativite teorileri kendinden kaynaklı açı̆̆a çıkan matematiksel sembollerin nasıl yorumlanması gerektiğine yardımcı olmakla birlikte deneylerden elde edilen sonuçları gündelik dil ile ifade edebilme adına uygun bir zemin hazırlamıştır. Özellikle cisimlerin boylarında meydan gelen kısalmaları ifade eden Lorentz dönüşümlerinin çok daha önceleri bilinip ve kullanılabilmesi rölativite teorilerinden kaynaklı dilin gündelik dil ile ifade edilebilmesi için uygun bir firsat olarak duruyordu (Öner, 2000).

Özel rölativite teorisi gündelik dil ile ifade edilecek olursa bu teoriyi meydana getiren sözcük ve onların anlamları arasında herhangi bir çelişki yok gibi gözükecektir. Yani özel rölativite teorisi gündelik dil ile anlamlandırıldığında rölativite kavramının geçtiği her alana bu teori rahatlıkla uygulanabilir sonucu ortaya çıkacaktır. Bundan dolayıdır ki bu teori ile yakın ilişki içerisinde olan cisimlerin boylarında meydana gelen Lorentz kısalmasının gerçek mi yoksa yanılsama $\mathrm{m}$ olduğu veya eş-zaman olma sözcüğünün anlamı olgulara bağlı olamayıp daha çok dildeki kavramlara bağlı gibi durmaktadır (Öner, 2000).
Bu ve buna benzer durumlar dil üzerinde yerleşik ilkelerden bahsetmenin çok da mantıklı olmadığını göstermekle birlikte dilin plastikleri gibi nedenleri olan bu anlam kaymalarının dil ve fizik arasında hem sabit hem de değişime açık bir yapıya işaret etmektedir (Şahinoğlu, 2018). Özellikle sürekli evrilen dil fenomeni içerisinde kavramların kullanılması, kullanılacaksa da nasıl kullanılmalı gibi genel geçer ilkelerden bahsetmek zor gibi durmaktadır (Öner, 2000).

1905 yılında rölativite teorilerinin birinci kısmı olan özel rölativite teorisini tamamlayan Einstein on yıl sonra ivmeli hareketleri de dikkate alarak kütle çekimini yeniden tanımlamış zaman ve mekana ait yeni bir dil gündeme getirmiştir. Genel rölativite olarak da bilinen bu yeni bakış, evrenin gerçekliğini izah eden iki büyük teoriden birisi olarak yerini almıştır (Arı, 2015).

Genel rölativite teorisinin başarısı "ikinci düşünme dili “devrimi”ni başlatması açısından oldukça dikkat çekicidir. Teorinin uygulamaya geçmesiyle o zamana kadar ki Öklit geometrisi kıstaslarının yetersiz olduğu kendini göstermiştir. Özellikle genel rölativite teorisiyle birlikte Öklitçi kesintisizlikten Öklit dışı dört boyutlu mekansal-zamansal kesintisizliğe ilerleyip olguların tüm ilişkilerini bu kesintisizlikle ifade edebilmesi (Cassirer, 2008) birçok filozofu da rahatsız etmiştir (Öner, 2000). Çünkü yeni fizik şimdi Öklit dışı geometrilerin sadece imkanını değil, aynı zamanda geçerliliğini de kanıtlamıştır.

Yeni fizik gerçek mekanda geçerli olan ilişkileri, sadece onları dört boyutlu, Öklit dışı çeşitliliğin dilinde ifade ettiğimiz zaman teorik olarak anlayip ortaya koyabileceğimizi göstermiştir (Cassirer, 2008). Yeni fiziğin genel rölativite teorisinde sergilediği dil gelişimi farklı geometrilerin epistemolojik eşitliği kavgasında değer kesinleştirici şeyin formel değil aşkın mantıkla aranabileceği, bu şeyin sadece geometrinin deneyimle uygunluğu değil, aynı zamanda "kanıtlı olarak kabul edilebilir" olduğu, yani deneyimin sunduğu hediyeye bağlı olduğu sonucunu doğurarak bu sonucun yalnızca Öklit geometrisinin ötesine geçildiğinde görülebileceğine inandırmıştır (Cassirer, 2008).

Öklit geometrisi her ne kadar farklı epistemik kaygıları gündeme getirse de deneysel düzeneklerimizin sahip olduğu sınırlar içerisinde kendini göstermesi aşkınsal mantığın önünde duran bir engel olarak vücut bulmuştur (Öner, 2000). Yani küçük boyutlarda genel rölativite teorisini matematiksel açıdan yorumlamak için Öklitçi dile başvurmaktan başka bir yol yok gibi durmaktaydı.

Küçük boyutlar açısından genel rölativite teorisine Öklitçi bir dil ile yaklaşmak bu teorinin kullandığı matematiksel semboller ve ölçümlerini gündelik dil ile ifade edilebileceği anlamına gelir. Fakat çok büyük boyutlar açısından Öklit geometrisinin anlamını yitirmiş olması bu teoriyi anlamlandırabilmek adına gündelik dilden uzaklaşmamız gerektiği gerçeği kabul etmemiz gereken bir durum olarak karşımıza çıkmıştır. (Heisenberg, 1964).

Küçük boyutlar için Öklit geometrisinin uygunluğu rölatiflik teorilerini tanımlamak için kullanılan dil ile matematikçilerin kullandığı dilin uyuştuğunu göstermektedir. Fakat deney sonuçlarını açıklamak için ise gündelik dile başvurulması bir "dikotomi”" olarak karşımıza çıkmaktadır. Özellikle kuantum teorisiyle birlikte kendini 
iyice belli eden dikotomisel yapı üzerinde konuşulması gereken bir durum olarak kendini göstermiştir.

\subsection{Kuantum Teorisi ve Dil}

Enerjinin sonlu paketler halinde var olduğu ve sonsuz küçüğe kadar bölünemeyeceği gerçeğine isim olan kuantum terimi, 1900'lü yıllarda fizik biliminin uzak bir köşesinde, 1şı̆̆ın nasıl salındığı ve yutulduğu ile ilgili kafa karıştırıcı meseleleri izah etme çabası ile ortaya çıkmıştır (Crease \& Goldhaber, 2016). Bu çabayı iki kuantum devrimi takip eder. Birincisi 1900-1925 yılları arasında bilim insanlarının bu teoriyi toplumun dikkatini çekmeden tartıştığ 1 ve geliştirdiği dönem, diğeri ise $1925-27$ 'de bu teorinin ortaya koyduğu tuhaf sonuçları toplumun merakını da cezbedip tartışma konusu haline getirdiği ve kuantum mekaniği diye adlandırdığı dönemdir (Crease \& Goldhaber, 2016). Seksen yıldan fazla bir süre sonra bugün dahi insanlık şaşırtıcı, düşsel ve hatta şok edici bulduğu bu ikinci kuantum devrimi ile ne yapacağ \& Goldhaber, 2016). Özellikle gündelik dildeki kavramları ikinci kuantum devriminin matematik sembolleri ile eşleştirecek herhangi bir kılavuz olmaması dilin kullanılışı yönünden bu devrimi anlamak adına ciddi karamsarlıklar ortaya koymuştur (Öner, 2000).

Kuantum mekaniği olarak adlandırılan ikinci kuantum devrimi ile birlikte atom ve ona ait kavramları gündelik dil ile açıklamanın imkansız olduğu görülmüştür. Her ne kadar ikinci kuantum devrimi ile gündelik dilden sıyrılmamız gerektiği açık olsa bile matematiğin biçimci ve aksiyomatik yaklaşımı bu devrim içerisinde de görülebiliyordu. Öyle ki kuantum mekaniğinin matematiksel şemasını atomun boyutları içerisinde klasik mekanik ile izah etmekten başka bir yol yok gibi durmaktaydı (Heisenberg, 1964). Fakat klasik istatistik teorisinden farklı olarak ortaya çıkan "olasılık girişimlerinin" sadece kuantum durumlarda kendini göstermesi çözümleri klasik fizik alanındaki çözümlere hiç benzemeyen kuanta-teorik çözümlere sadece büyük boyutlar içerisinde de rastlamamız klasik çözüm anlayışına ihtiyatla yaklaşmamızı gerektirmiştir (Öner, 2000).

Öner'e (2000) göre mikro dünyayla ilgisi olan bu büyük boyutlu kuantum sistemi, klasik istatistikte göremeyeceğimiz yeni bir "istatistik öğe" gündeme getirmesinden dolayı yorum tarzımıza yeni bir bakış açısı kazandırmıştır. Bu istatistik öğe olasılıklardan dolayı ortaya çıkan girişimleri etkileyerek kuantasal yorumlanması gereken olayların klasik fizik açısından yorumlanmasına neden olmuştur. Bu durum ise kuantum teorisine ait olan matematik dili ile gündelik dilin yakınlaşması sonucunu doğurmuştur. $\mathrm{Bu}$ yakınlaşma tabiatıyla deney sonuçlarının gündelik dil ile yorumlanması fikrini ortaya atmıştır (Öner, 2000).

Kuantum dili ile gündelik dil arasında ittifak yapılamaması kuantum devriminin beraberinde getirdiği dil problemleri olarak tanımlanabilir. Özellikle atomu algılayabilme veya tanımlayabilme nazarında net konuşabilme hakkını insanoğlunun elinden alınması bu devrim ile ilgili birtakım soruları kendilerine sorma zorunluluğu hissettirmiştir. Bu sorular içerinde özellikle kuantum devriminden beri fizikçilerin konuşma tarzının ve kuantum devriminin mantıksal yapısı ile uyumlu bilimsel dilin ne olduğuna soruların karşımıza çıktığını görmekteyiz (Öner, 2000).

\subsection{Kuantum Devriminin Açığa Çıkardığı Sorular}

\subsubsection{Kuantum Devrimi ve Fizikçilerin Konuşma Tarzı}

Son üç yüzyıl boyunca Batı bilimsel düşünüşünün temel hamlesinin indirgemeci (reductionist) yaklaşım olduğunu düşündüğümüzde kuantum devriminin yarattığı etkinin bu anlayış üzerinde ivedi bir şekilde etkili olacağı düşünülemezdi. Özellikle geniş düzlemlerdeki çözümleme kelimesinin kullanılışı, bilimcinin problemi çözmek için problemin bir parçasını almasına dair vazgeçilmez alışkanlığı indirgemeciliğe olan düşkünlüğünün kanıtlarıydı (Davies, 1994).

Kuantum devrimi ile beraber aşırı indirgemeciliğin kötülükleri, keskin eleştirileri üzerine çekmiştir. Öyle ki bu konuda yazar Arthur Koestler (1979; akt. Davies, 1994, s. 134-135), “Kör güçlerin karşılıklı etkileşimindeki değerler anlam ve amaç için, bir işi reddetmeyle, indirgemeci tavır, bizim bütün kültürel ve politik iklimimizi bile etkileyen, bilimin sınırlarının ötesine gölge düşürmüştür" diyerek bazı problemlerin birleştirilmek sureti ile çözülebileceğini yani bu problemlerin doğada sentetik ya da "bütüncül" (holistic) olarak ele alınması gerekliliğinin altını çizmiştir. Tüm bu ifadeler kuantum devrimi ile beraber fizikçilerin evreni ve ona ait olayları tanımlayabilme adına "holistik dili" daha çok kullanma eğilimine girdiklerini göstermektedir. Özellikle kuantum kuramının tekmil maddenin maddeyi oluşturan parçaların bütününün, onu oluşturan bölümlerin doğrusal ve kartezyen toplamı olduğu şeklindeki atomik çözümleyici yaklaşımının tatmin edici olmadığını söyleyerek indirgemeciliğe karşıt bir tanımda bütüncülük (holism), parçadan bütüne değil, bütünden parçaya doğru ve yeni bir biçimde ele alınması gerekliliğini savunarak (Işıklı, 2012) holistik dili kullanabilme adına bir kapı aralamıştır. Verçin'e (2001) göre bütüncülük ya da holism kuantum sistemler ve sistemi oluşturan unsurlar arasında yeni biçimde parça-bütün ilişkisinin kurulmasını sağlayan ilkelerdir. Bütüncülüğe göre, bütün kendisini oluşturan parçaların toplamından daha fazla bir şeydir. Bütün parçaların basit toplamı olamaz. Chibeniye'e (2004) göre ise tekmil madde ya da sistem unsurlarının ne birbirlerinden ne de bütüncül yap1 özelliklerinden bağımsız tekil bir mevcudiyetleri bulunmaz. Başka bir deyişle bütüncül bir sistemde unsurların ontolojik ilişkisizliği söz konusu olamaz. Işıklı (2012), kuantum devriminin sadece tek bir bütüncülüğü ortaya çıkarmamış beraberinde EPR bütüncülüğü, Bohr bütüncülüğü ve Bohm bütüncülüğü gibi aralarında hem epistemolojik hem de ontolojik ayrımlar bulunan yaklaşımlarında da kendini gösterdiğini ifade etmektedir. Kuantum devrimiyle birlikte daha çok konuşulmaya başlanan bütüncül ya da holistik dil özellikle dolanıklık olarak bilinen olayda kendini daha çok hissettirmiştir. Özellikle EPR deneyinde kendini gösteren dolanıklık olayı Einstein, Podolsky ve Rosen tarafindan yerel olmayan etkileşimleri çürütmeye yönelik tasarlanmış bir düşünce deneyidir (Gribbin, 2006). Bir EPR düzeneği buçuklu spin ve iki nesneden oluşan bir sistem olarak düşünebiliriz (Susskind \& Friedman, 2017). Bu tür sistemlerin en bariz özelliği iki değerli olduklarından dolayı spinlerinin dolanıklık özelliği göstermeleridir. Bu özellikleri A ile temsil edip değerlerini ise $+1 / 2$ ile $-1 / 2$ olarak alabiliriz. Spin bileşenlerine ait gözlem sonuçlarından biri $+1 / 2$ ise diğeri -1/2 olur. Çünkü kuantum teorisi iki nesne üzerindeki aynı yön boyunca spin bileşenlerinin ölçüm sonuçlarının kesinlikle dolanıklı olmasını öngörür (Işıkl1, 2012). Bu tür 
bir A sistemi de tıpkı klasik bir sistem gibi tüm zamanlar için kesin bir değere sahiptir. Olaya gündelik dil açısından yaklaşıldığında en azından karşımıza böyle bir tablo çıkar ki bu durum zaten klasik fizik yasaları içerisinde korunum yasası olarak bilinir. Bu deneyde fizikçilerin kullandıkları dolanıklık terimi ve onu meydana getiren nesne çiftleri bir kaynakta üretilirken fiziksel olarak meydana gelmektedirler. Nesneler ayrı ayrı yol alırken kendilerine ait olan A özelliklerini tüm zaman boyunca yanlarında taşırlar ve yapılan herhangi bir ölçüm işlemi de taşınan özelliği açığa çıkarır (Chibeni, 2004). Ölçüm sonuçlarının dolanıklaşmasını gündelik dil açısından dikkate aldığımızda bu olayı klasik fizik ve mantıksal açıdan açıklamanın mümkün olduğunu görebiliriz. Einstein (akt. Omnes, 2017) ise dolanıklaşmanın imkânsız olduğunu bu yüzden kuantum teorisinin eksik olduğunu ileri sürmektedir. Gündelik dil ile ifade edilen Einstein ifadelerinin yeni fiziğin dili ile çatışma halinde olduğunu söyleyebiliriz. Çünkü dolanıklaşma gibi yeni fizikten kaynaklanan dil ürünleri olan alternatif açıklama yöntemleri görelilik kuramıyla büyük bir savaş halindedir. Aslında burada gündelik dilden kaynaklı açıklamayı engelleyen şey bağlılaşıklığın olağan açıklamasında tek sorumlu bireysel bir nesnenin ölçümünden önce bir A değerine sahip olmamasıdır. Toplam sistemin A özelliğine kesin bir değer yüklenebilirken onun bileşenlerinin özelliğine aynı değerin yüklenememesidir. Bu nedenle Einstein'e göre fiziksel özelliklerin yeni fizik dilinden kaynaklı kuantum mekaniksel tasvirleri yanlış olmasa da eksiktir (Ișıklı, 2012). Chibeni’ye (2004) göre bu durum çözümleme yönteminin açık bir başarısızlığıdır. Bunun nedeni olarak ise EPR fizikçilerinin kuantum olguları gündelik dilden kaynaklı bilimsel çözümleme yöntemlerine göre ele almalarından kaynaklandığını ileri sürmektedir.

Kuantum devrimi ile ortaya çıkan diğer bir dil anlayışı ise sistemlerin tersinir olup-olmama durumuna ait yapilan reddiyedir. Bilindiği gibi gündelik dilden kaynaklı sistemlerin en bariz özelliği tersinir olmalarıdır. Başka bir deyişle klasik yasalar sıra değişimli bir yapıya sahiptirler. Böyle bir sistemde olaylar tersinirdir. Ve sistemin önceki koşullarını yok etmez (Işıklı, 2012). Gündelik dilden kaynaklı sistemlerde entropik zamansallıkla işleyen yasalarca yönetilen bir belleğe sahip olduğundan gözlenenin şimdiki durumu hem geleceğe dair özdeyiye hem de geçmişe dair art deyiye izin verir (Verçin, 2001). Gündelik dilin ürünü olan sistemlerde sistemler tersinmez, yasaları ise sira değişimsizdir. Fakat sıra değişimsizlik ontolojik gerçekliği değil, epistemolojik noksanlığı imler (Verçin, 2001).

Kuantum devrimiyle birlikte reel nesneler üzerindeki belli ve özel bir değerin gözlenmesiyle elde edilen ölçümlerin olasılık genliğinde sanal olasılıklardan yalnız birinin edimselleştirilmesiyle meydana gelmesi sistemin geçmiş koşullarını tekrar türetilemez gerçeğini doğurmuștur. Yeni fiziğin ürünlerinden olan kuantum devrimi "kuantum gerçeklik" olarak bilinen bir realite açığa çıkarmıştır. Öyle ki bu gerçeklik gözlemcinin edimiyle dolayım içinde bulunmaktadır (Verçin, 2001).

\subsubsection{Kuantum Devriminin Mantiksal Yapısı ile Uyumlu Bilimsel Dil}

Düşünmenin ana ilkeleri birçok insan tarafindan kabul edilen yaklaşımlardır. $\mathrm{Bu}$ ilkeler günlük hayatın ayrılmaz birer öğeleridir. Öyle ki gündelik dilin her unsuruna kadar yerleşmiștir. Özlem (2004), çıkarım ya da dedüktif akıl yürütmenin ilkelerini ya da kanıtlama yöntemlerini araştıran formel disiplini mantık olarak tanımlamaktadır.

Descartes her insanda mantığın olduğunu ileri sürerek mantık ilkelerinin doğuştan gelen ideler olup aynı zamanda evrensel olduğunu da vurgulamaktadır ( Işıklı, 2012). Descartes'a göre doğuştan a priori ve açık seçik olan mantık ilkeleri, Aristoles'e göre evrenseldir ve nesnenin doğasına uygundur. Ne Aristoles'te ne de Descartes'te mantık, dünyanın tasvirinin tam uygun araçları olmaktan başka bir yargıyla değerlendirilemezler (Aristoteles, 2002). Klasik mantık birçok bakımdan sağduyumuzla uyumlu olduğundan konuştuğumuz gündelik dil ile büyük bir paralellik doğurmaktadır. Başka bir deyişle gündelik dil klasik mantığın ilkelerini ifade eden temel bir parametredir diyebiliriz. $\mathrm{Bu}$ anlamda kategoriler dilin veya mantığın özgün kalıpları değil tasvir ettikleri varlığın özgün anlarıdır. Yani mantık ile varlık arasında bir örtüşmezlik iddiası gündeme gelemeyeceği gibi mantık ilkelerinin basit gündelik deneyimlerden türetildiği ve insani değerler içerdiği de düşünülmez. Burada çok temel bir varsayım kendini gösterir. "Dil” dünyanın tam tasviridir (Işıklı, 2012). Woods ve Grant'a (2011) göre klasik mantık da diğer düşünme biçimlerinde olduğu gibi basit deneyimlerden türer. Bundan dolayıdır ki gündelik dil ile klasik mantık arasında bir uyumsuzluk beklenemez. Makrokosmosdan elde edilen gözlemlerden hareketle sağduyuya uygun bir mantık inşa edilmiştir.

Sağduyu ve gündelik deneyimler ile mantık ve matematik gibi biçimsel disiplinlerin temel aksiyomları arasında bir bağ kurulmasının hiç de sağlıklı olmadığı alternatif geometriler tarafından gösterilmiştir. Klasik mantığın en köklü problemi kendini oluşturan ilkeleri ile ilgilidir. Mantık, kendi varsayımlarını ispatlayamamaktadır. $\mathrm{Bu}$ anlamda mantığı meydana getiren aksiyomların çok da "mantıklı" olduğu söylenemez. Klasik mantık kendi aksiyomlarını haklı çıkarmak için apaçıklık, a priori ve tümsellik gibi parametrelere başvurur (Işıkl1, 2012). Tüm bu parametrelerin gündelik deneyimlere bağlı olduğu aşikârdır. Fakat mantığın kendisinin deneyim ve sağduyuya göre kurulduğu halde ilkelerinin gerek deneyim gerekse deneyler tarafindan geçersiz kılınamayacağı şeklinde bir paradoksla karşılaşıyoruz. Bu paradoksal görünüşün altında yatan neden ise Platoncu gerçeklik inancından kaynaklandığını söyleyebiliriz (Woods \& Grant, 2011).

Tüm bilgilerimizin ana noktası ve bir o kadar da sorunlu olan klasik mantığın temel ilkeleri (Öner, 1986) :

I. Özdeşlik ilkesi $(\mathrm{A}=\mathrm{A})$

\section{II. Çelişmezlik İlkesi $(\mathrm{A} \neq \mathrm{A})$}

III. Üçüncü Halin İmkânsızlığı $(\mathrm{A} \neq \mathrm{B})$ maddelerinden meydana gelmektedir.

Klasik mantığın indirgemeci doğası ve klasik mekaniksel uygulamaları yeni olgular karşısında eksik kalmış ve holistik bir yaklaşımı gündeme getirmiştir (Landau, 2013). Bu holistik yaklaşımı Woods ve Grant, klasik mekanik ile kuantum mekaniği arasındaki ilişkiyle değerlendirir. Özellikle diyalektik mantık açısından değerlendirdikleri holistik yaklaşımı kuantum mekaniği ile örtüştüğünü ileri sürmektedirler. Kuantum evreni, klasik yasaların egemen olduğu evrenlerden farklı olan yasalar tarafindan yönetilir. 
Kuantum nesneler klasik mantığın ilkeleri ile anlatılamaz. Bu yüzden klasik us, aralarında ayrım olmayan elektronlara aynı anda farklı yönlere doğru hareket eden hem dalga hem de parçacık karakterlerine sahip olan parçacıklara uygulanamaz (Landau, 2013). Gündelik dilden kaynaklanan klasik ölçümler kuantum olaylarına uygulanamaz. Çünkü her bir süreç ancak kendi etki sınırlarında geçerlidir. Kuantum etki sınırları içerisinde klasik mantık ve matematiksel şema işlevsel olma niteliğini kaybetmektedir. Kuantum durumlar, günlük deneyimlerimiz ile örtüşmeyen bir olguyla karşı karşıya olduğumuzu göstermektedir (Işıklı, 2012).

Klasik mantığın ilkelerinden olan Özdeşlik İlkesine göre makro nesneler için belli bir uzay ve zaman parametresinden bahsedebiliriz (Işıkl1, 2012). Herhangi bir nesnenin orbitalini başka bir nesnenin işgal etmesi klasik mantığa aykırıdır. Fakat kuantum nesneleri için bu durum çok da önemli değildir. Kuantum parçacıkları için özdeş birer tekillik durumundan bahsedemeyiz. Kuantum gerçeklik için kabul edilen olasılık genliği kuantum parçacıkların konumları hakkında kesin bir yargı vermez. Bu bakımdan kuantum nesneleri, klasik mantığın ayrım ilkesini ihlal etmektedirler (Işıklı, 2012). Yani herhangi bir kuantum parçacığı hem A'dır hem de B'dir. Hem A'dır hem de A-değildir. Hem parçacıktır hem dalgadır. Ortaya çıkan bu ilginç durumlar kuantum olgularının tasviri için yeni bir mantığa gereksinim olduğunu göstermektedir (Işıklı, 2012). Bu mantığın bütüncülük, dolanıklık, yerel olmayan etkileşmeler, kesinsizlik ve belirsizlik ilkelerini karşılaması gerekmektedir (Bugajska \& Bugajska 1973).

Tümdengelim yerine kuantum bütüncülüğü, ayrım yerine dolanıklık, çelişmezlik yerine kesinsizlik, belirlenimcilik yerine belirlenimsizlik İlkeleri getirilmelidir. Bu durumda klasik mantığın temel ilkelerinde yapılacak herhangi bir düzeltme, genişletmeye değil, tümüyle yeni bir mantığa yol açar. Yeni mantık ise bu aksiyomların değiştirilmesiyle elde edilebilir (Işıklı, 2012). Yani;

\section{I. Özdeş-sizlik ilkesi $(\mathrm{A} \neq \mathrm{A})$}

\section{Ayrım-sızlık ilkesi $(\mathrm{A}=\mathrm{B})$}

III. Çelişki ilkesi (A $\square \mathrm{A})$ şeklinde yeni mantık ilkelerine ihtiyaç olduğu söylenebilir.

Gündelik dil ile kurulan klasik mantığın biçimsel mantık olarak değerlendirilmesinin nedeni kuantum mantığında ortadan kalkar. Dolayısıyla biçimsel mantık açısından yapılan eleştirel, kuantum mantığa yöneltilemez. Kuantum mantığı, yerel olmayan etkileşmeler, dolanıklık, bütüncülük, dalga-parçacık dualitesi, fiziksel sistemin evrilmesi gibi konularda gözlemcinin işin içine dâhil olduğu edimsel durumları tasvir eder. Bu durum onu biçimsellikten kurtarır, edimsel hale getirir. Bunun sonucu olarak ise kuantum biçimselliği klasik mantığın üç ilkesini ihlal eder. Bunun kanıtı olarak ise fiili gözlemi söyleyebiliriz. Yani özne önermenin doğruluğunun kaynağı ve kriteri haline gelmiştir. Salt kuantum biçimselliği içinde kalınarak hiçbir epistemolojik ilerleme sağlanamaz (Işıklı, 2012).

\section{Sonuç}

Geçen yüzyıl içerisinde fizik bilimine birçok yeni kavramlar girmiştir. $\mathrm{Bu}$ yeni kavramlar bir kaos ortamı yaratmakla birlikte insanı hayrete düşürecek birçok önemli sonuçları da beraberinde getirmiștir. Yani kavramlar akabinde "yeni fizik" olarak adlandırılan bir fiziğin inşasında öncü rol oynamıştır. Bu yeni fizik içerisinde özellikle elektromanyetik alan kavramı, Maxwell gerçekleri, görelilik ve kuantum teoremleri fizikçilerin gündelik dili kullanmalı mıyız sorusunu kendilerine sorma imkânını vermiştir. Her ne kadar yeni fizik olayları kendisiyle orantılı bir dil ile kullanılmasını mecbur bıraksa da birçok fizikçi tarafından bu dil çok sonraları kullanılmıştır. Çünkü bu kavramların yerleşmesi bilimdeki köklü tasarımlarımızın değişmesine bağlıydı ve böyle köklü değişimler de aslında hiç de öyle kolayca ve birdenbire meydana gelmiyordu (Heisenber, 1964).

Yeni fizikten kaynaklı açığa çıkan yeni kavramların uygulama alanı geniş tutarlı ve kapalı bir sistem meydana getirmekle kalmadı aynı zamanda öyle bir dil ortaya çıkardı ki bu dil yalnız fizikçiler tarafından değil teknisyenlerden mühendislere kadar tüm kesim tarafından kullanılmaya başlandı (Öner,2000). Determinist-mekanist bir evren anlayışından indeterministik bir evren modeline geçiş hep bu dilin bir uzantısı olarak kendini gösterdi. Özellikle olayların zaman boyunca sıralanış biçiminin uzay-zaman döngüsü içerisindeki düzenleme biçimlerinden bağımsız olduğu şeklindeki varsayımlar hep bu yeni fiziğin tasarımları arasında kabul edilmektedir. Bunun yanı sıra Öklit uzayından Mikowski uzayına olan evrilmeler ve Riemann geometrisine geçiş bu dilin sonuçları arasında gösterilebilir. Yeni fizik ile açığa çıkan dilin meydana getirdiği en büyük antinomi kuantum teorisi ile kendini göstermiştir. Özellikle gözlem sürecinin gözlenen olay üzerine belirli bir etki yaptığı gerçeği holistik anlayışın taraf bulmasına neden olmuştur. Bu dil, gözleyen ve gözlenenin bir bütün olarak ele alınmasını gerektiğini söyleyerek gündelik dil ile aralarında olan uçurumu iyice artırmıştır. Gözlenen ve gözleyen arasındaki holistik ilişki yeni fizikten kaynaklı dilin fiziğe tüm bilimlerin temeli sayılan objektiflik idealinin gerçekleşmesi yolunda gerekli bir koşul olduğunu göstermiştir (Öner, 2000).

Sonuç olarak yeni fizikten kaynaklı dil, olgularla yani deney sonuçlarıyla temellendirildiği taktirde, mantık ilkelerinin karşımıza çıkardığı aksiyomatik ve sembolik zorluklardan kurtarıp gündelik dil ile arasında bir köprü inşa edeceği gerçeğini karşımıza çıkarmıştır.

\section{Kaynakça}

Akarsu, B. (1998). Dil-Kültür Bağlantısı. 3. Baskı. İstanbul: İnk1lap Kitabevi.

Aksakallı, A. (2019). Modern Fizik Öğretiminde Kavramların Algılanması. 1.Baskı. Erzurum: Ertual Akademi Yayıncılık.

Altuğ, T. (2000). Dile Gelen Felsefe. İstanbul: YKY.

Arı, V. (2015). Rölativite'denKuantum'a. Evrenin Gerçekliği. 1. Bask1. İstanbul: Bilgi Üniversitesi Yayınlar1.

Aristoteles (2002). Kategoriler. Çev. Saffet Babür. 2. Baskı. Ankara: İmge Kitabevi. 
Bugajska, K. \& Bugajska, S. (1973). "TheLatticeStructure of Quantum Logics". Annales de I'I. H.P. Section A, Volume XIX, 333-338.

Capra, F. (1998). Batı Düşüncesinde Dönüm Noktası. İstanbul: İnsan Yayınlar1.

Cassirer, E. (2008). Rölativite Teorisi Üzerine Felsefi Inceleme. Çev: Milay Köktürk. Ankara: Hece Yayınları.

Chibeni, S.S. (2004). Holism in Microphysics Epistemologia. Vol 27(2).

Crease, R.P.,\& Goldhaber, A.S. (2016). Kuantum Dönemi. Planck, Bohr, Einstein ve HeisenbergBelirsizliği Sevmeyi Bize Nasıl Öğretti.Çev: Vural Arı. 1. Baskı. İstanbul: Bilgi Üniversitesi Yayınlar1.

Davies, P. (1994). Tanrı ve Yeni Fizik. Çev: Murat Temelli. 2. Baskı. İstanbul: Alfa Yayıncılık.

Ergin, M. (2013). Türk Dil Bilgisi. İstanbul: Bayrak Yayınları.

Foucault, M. (2017). Kelimeler ve Şeyler. 6. Baskı. Ankara: İmge Kitabevi.

Gribbin, J. (2006). Schrödinger'in Kedisinin Peşinde. 2. Bask1. İstanbul: Metis Yayınları.

Heisenberg, W. (1964). İdealizm. Determinizm'den Olasılı̆̆a Doğru. 3. Baskı. İstanbul: Belge Yayıncilik.

Hoffman, B. (1992). Einstein. Yaratıcı ve Başkaldıran. Çev. Celal Kapkın. 1. Baskı. İstanbul: Evrim Yayıncılı.

Işıklı, Ş. (2012). Kuantum Felsefesi. Postmodern Bilimin Doğuşu. Ankara: Birleşik Yayınları.

Kohestler, A. (1979). “Nothing but...?”, LyingTruths (eds. K. Duncanand M. Weston-Smith; Pergemon).

Landau, L. D. (2013). TheClassicalTheory of Fields. Vol (2).
Nagel, E.,\&Newman J. (2010). Gödel Kanıtlamast. Çev. Bülent Gözkan. 3. Baskı. İstanbul: Boğaziçi Üniversitesi Yayınları.

Omnes, R. (2017). Kuantum Felsefesi. Çev. Ercüment Akat. 1. Baskı. İstanbul: Alfa Yayıncılık.

Öner, M. Y. (2000). Fizik ve Felsefe. Diyalektik Olasıllktan Determinizme Doğru. 3. Bask1. İstanbul: Belge Yayıncilık.

Öner, N. (1986). Klasik Mantık. 5. Baskı. Ankara: Ankara Üniversitesi İlahiyat Fakültesi Yayınları.

Özlem, D. (2004). Mantık-Klasik/SembolikMantık/Mantık Felsefesi. 9. Baskı. İstanbul: Inkılap Kitapevi.

Russell, B. (2013). Rölativitenin ABC'si. Çev. Vahap Erdoğdu. 3. Baskı. İstanbul: Soy Yayınları.

Smolin; L. (2018). Fiziğin Krizi. Çev. Tonguç Rador. 1. Baskı. İstanbul: Alfa Yayıncılık.

Soykan, Ö.N. (2016). Felsefe ve Dil. 1. Bask1. İstanbul: Bilge Kültür Sanat Yayınları.

Susskind,L.,\&Friedman, A. (2017). Kuantum Mekaniği. Çev. Zekeriya Aydın. 1. Baskı. İstanbul: Alfa Yayıncılık.

Şahinoğlu, A.O. (2018). Tractatus: Mantıksal Pozitivizme İçeriden Bakmak. Düşünbil. Aylık Felsefe Dergisi. 72, $15-17$.

Ural, Ş. (1998). Bilim Tarihi. 2. Baskı. İstanbul: Kırkambar Yayınları.

Verçin, A. (2001). "Harekete İki Farklı Bakış: Determinizm ve Atomizme Karşı Olasılıkçı1ık" ve Bütüncülük. Popüler Bilim. Say1: Ağustos 2001.

Woods, A. \& Grant, T. (2011). Aklın İsyanı. Markist Felsefe ve Modern Bilim. Çev: Ömer Gemici, Ufuk Demirsoy. 5. Baskı. İstanbul: Tarih Bilinci Yayınları.

Yüksel, H. G. (2009). Felsefenin Gözü İle Dilin Bazı Problemleri. Trakya Üniversitesi Sosyal Bilimler Dergisi, 11(1), 151-163. 